\title{
Global Position of the US Economy and Its Impact on the Economy of the Czech Republic
}

\author{
Linda Pudilová ${ }^{1 *}$, and Kamila Veselá ${ }^{1}$ \\ ${ }^{1}$ Czech University of Life Sciences Prague, Faculty of Economics and Management, Department of \\ Economic Theories, Kamýcká 129, 165 00, Prague, Czech Republic
}

\begin{abstract}
.
Research background: The economy with the strongest influence on world affairs, international politics and world economy is undoubtedly the economy of the United States of America. In the Czech Republic, after the revolution, the USA quickly came to the forefront of interest and mutual foreign trade grew significantly. However, their global influence was significantly reflected not only in economic aspects, but also in sociological aspects. In recent years, the so-called "Americanization" has been taking place in the Czech Republic. American terms were often adopted in the commonly used Czech language, and the demand for American goods increased significantly.

Purpose of the article: The objective of the presented text is to evaluate development of the influence of the USA on the economy of the Czech Republic by analysing the development of key macroeconomic quantities, in particular gross domestic product, gross national product, balance of payments and foreign trade. Based on the results of this analysis, the future development of the Czech economy, more precisely opportunities and impacts arising from mutual trade relations between the American and Czech economies, is predicated.

Methods: Descriptive statistic.

Findings \& Value added: The results of the research showed a gradual expansion of the influence of the American economy in the Czech Republic, which began after 1989 and continues to this day. This influence manifested itself in several aspects. It was reflected in the structure of mutual foreign trade, and also in the Czech culture and the Czech language (adoption of English terms into the Czech language).

The further potential of mutual trade is highlighted out by comparing the structure of export and import from the USA in total and export and import from the USA to the Czech Republic.
\end{abstract}

Keywords: Czech Republic; USA; economy; foreign trade; hegemon; trade policy

JEL Classification: $F 15$; F17; F43.

\footnotetext{
${ }^{*}$ Corresponding author: pudilova@pef.czu.cz.
} 


\section{Introduction}

USA has long been considered to be the world's strongest economy, a hegemon, and a country with the greatest impact on global affairs, although there are increasingly frequent discussions on China's possible rise and assumption of the position of a world superpower. The nature of USA as a world hegemon and power is determined by many factors, such as a stable economic growth, impact on global affairs via a sufficient representation in international organisations, and also influence on global events and population. Consequently, the Czech Republic is characterised by a number of phenomena where the effect of the U.S. economy on the country and her inhabitants is evident. The so-called "Americanisation" of society is often mentioned in this regard.

Marvel [1] analyses U.S. trade flows, emphasising imports, as well as their price and effect on domestic producers. He points out that imports give the U.S. economy control over the ability of domestic business to remain competitive. Lipsey [2] studies the U.S. trade from the early 19th century to the 1910 s, stating that agricultural products were the main exports of the United States at the time. Due to the growing expanse of agricultural land and dropping transportation costs, exports of American agricultural products to Europe increased, promoting - among other things - migration from Europe. The size of the global, relatively open market made it possible for U.S. comparative advantages with a high price elasticity to increase the demand for U.S. agricultural exports. Shepherd [3] assesses the structure of the U.S economy in 1909-1970, pointing out a growing aggregate production in the manufacturing sector. He also concludes that the U.S. economy was highly competitive as the scope of economic competition skyrocketed in 1958-1980. Davis [4] analyses recent history. Meanwhile, Hanson [5] observes that while international trade was a key concept and (a substantial part of GDP) for European economies, this was originally not true for the U.S. economy on account of the size of its domestic market. Speaking long-term, the U.S. economy is stable and growing. Kahn [6] concludes that investing in inventory, especially with respect to durable goods, is an important factor in lowering economic volatility. He also confirms the conclusions of Jorgensona [7] who points out the necessity of technology investments if a stable economic growth and the economy's competitiveness are to be ensured. This is one of the reasons why China has made significant science and research investments lately - in 2018, China invested only 50 billion USD less (500 billion USD in total) than the United States of America. Using tools other than performance statistics, Strange [8] analyses who really controls global policy. To do this, he uses such concepts as power and politics, striving to give a broader view of global economy functions and dispersed authority within the global economy. He assumes that territorial borders of states where sovereign jurisdiction is exercised do not necessarily correspond with the scope (limit or overlap) of political authority.

Since 1989, the Czech Republic has been an open economy, availing herself of the benefit of comparative advantages provided by international exchange. Abboushi [9] confronts protectionism with free trade and arrives at the conclusion that the cost of protectionism usually exceeds its benefits and generally is not profitable for the economy. The issue of the degree of protectionism in global trade is associated with barriers to foreign trade which (especially when based on political consensus) are crucial to global trade and its liberalism. Niu a kol. [10] observes that due to the increase of non-tariff barriers to trade in case of most countries and products, the degree of protectionism did not decrease between 1997 and 2015. The goal of this article is to assess the global influence of the U.S. economy and its impact on the Czech Republic. Research questions were formulated to achieve this goal. Research question 1: How does the U.S. culture impact the culture of the Czech Republic? Research question 2: How does the U.S. economy affect the economy of the Czech Republic? Research 
question 3: Is there a relationship of dependence between the Czech and U.S. gross domestic product?

\section{Methods}

The article is based on secondary data, sourced mostly from the World Bank and Eurostat database. Considering the origins of the Czech Republic, time series are analysed no further than 1990. The impact which USA's global influence has on the Czech Republic is analysed in several steps. First, in order to answer research question 1, a survey on the impact of the U.S. culture on the culture of the Czech Republic is performed. Here, data collection and evaluation is a crucial method. The method for answering research question 2 mostly consists in analysing and comparing the U.S. and Czech gross domestic product. The structure of mutual foreign trade of both countries is also studied by analysing and comparing the time series of mutual exports, imports, and nett exports. The analysis of time series observes their trends and trend deviations, both in terms of absolute and relative indicators. To answer research question 3, dependence and correlation analysis is performed in order to determine whether the performance of the U.S. economy directly influences the performance of the Czech economy. The method of trend analysis and regression statistics was used. The selection of a suitable trend function was made by an usage and evaluation of the interpolation criteria. The selected function has the smallest possible value of the MSE criterion, qualifies the F-test and a has sufficiently high confidence value of $\mathrm{R}$. The MSE value is determined using the function:

$$
M S E=\frac{\sum_{t=1}^{T}\left(-\widehat{y_{t}}\right)^{2}}{T}
$$

where $\mathrm{T}$ is the number of observations, $y_{t}$ are the measured values and $\widehat{y_{t}}$ are the expected values. Linear and quadratic curves were used as basic with respect to the development of time series. With regard to the development of time series, linear and quadratic curves were used as basic ones.

\section{Results and discussion}

As a world hegemon, the U.S. economy significantly influences all other economies, i.e. the EU and Czech economy as well. After 1989 when the Czech economy opened itself to the foreign trade, the United States were viewed by many citizens as a model example and ideal type of economy. Thus, the United States began increasingly penetrating not only the Czech economy, but also the thinking of Czech people. The so-called "Americanisation" of society is often mentioned in this regard, meaning the adoption of characteristically U.S. values in other parts of the world (the Czech Republic in this case), as well as a submission to the political, economic, and cultural influence of the USA. Moreover, it can be argued that Americanisation is a part of increasing globalisation. In the Czech Republic, Americanisation can be divided into several segments by the area where it's the most apparent, as shown by Table No. 1.

Table 1. Americanisation of the Czech society

\begin{tabular}{|l|l|}
\hline Type of impact & Manifestation \\
\hline \multirow{3}{*}{ Political } & Effect of the U.S. GDP on the Czech GDP \\
\cline { 2 - 2 } & Effect of the U.S. GDP on Czech exports and imports \\
\hline \multirow{2}{*}{ Sociological } & Language-Anglicisms and Americanisms \\
\cline { 2 - 2 } & Increasing benevolence to different cultures \\
\hline
\end{tabular}




\begin{tabular}{|l|l|}
\multirow{4}{*}{ Cultural } & Inspiration provided by the "consumerist" lifestyle \\
\cline { 2 - 3 } & Inspiration provided by the "American dream", efforts to achieve it \\
\hline Music_a number of American performers in the Czech media \\
\cline { 2 - 2 } & Music_Czech performers singing in English \\
\cline { 2 - 3 } & Fast food boom and its influence on the eating habits of Czechs \\
\cline { 2 - 3 } & Prevalence of U.S. movies on Czech TV stations \\
\hline
\end{tabular}

Americanisation, i.e. the adoption of products, behaviour, and general lifestyle patterns, is clearly evident in several areas in the Czech Republic. In terms of those which are not related to economy, let us mention the cultural impact of the USA as the Czech media is dominated by U.S. performers (both with respect to music, and cinema). Moreover, Czech artists (especially musicians) frequently prefer English to Czech. Changing eating habits are another cultural area which is affected by Americanisation, primarily due to a growing number of fast food restaurants. This is closely related to the negative effects this unhealthy lifestyle has on the overall health of the Czech nation. Prevalence of foreign vocabulary in the Czech language, namely Anglicisms and Americanisms, is another important area where the influence of the United States is evident; words like meeting, notebook, PR, HR, hot dog, burger and many others are used instead of Czech terminology.

Historically speaking, Americanisation can be observed in several stages. The first relevant stage occurred after WWI when the United States already began playing a key role in the global economy, enjoying a significant-mostly economic-influence on other countries. Second, the process of Americanisation manifested itself after WWII when other countries started adopting the model of corporate governance. In the Czech Republic, the third wave of Americanisation arrived in the late 1990s when the Czech economy, culture, and essentially all aspects of regular life increasingly began feeling the influence of the U.S. economy. This was strongly facilitated by the events of 1989 and the opening of the Czech economy.

The following text focuses on the economic impact of the U.S. economy's influence on the Czech Republic.

In the first stage, we analyse the development of the gross domestic product (expressed in real and nominal terms) in the reference period 1990-2018 in the Czech Republic, United States of America, and European Union. To facilitate a comparison between these markedly different entities, data is converted to a gross domestic product per capita. For this purpose, a formula where GDP per capita = regular value GDP/population size is used. Chart No. 1 captures the development of this indicator, expressed in US dollars. The development of gross domestic product per capita in the USA, the EU and the Czech Republic shows a growing trend, which can be described by a linear function. An overview of the results of the regression analysis is presented in the following table.

Table 2. Results of regression statistics

\begin{tabular}{|l|c|c|c|c|c|c|}
\hline & $\begin{array}{c}\text { Confidence } \\
\text { value (R) }\end{array}$ & SS Rezidues & MSE & F-test ("P") & $\begin{array}{c}\text { parameter } \\
\mathrm{a}\end{array}$ & $\begin{array}{c}\text { parameter } \\
\mathrm{b}\end{array}$ \\
\hline $\begin{array}{l}\text { GDP/US } \\
\text { pop. }\end{array}$ & 0.991754 & 36188446.98 & 1206281.57 & $1.00758 \mathrm{E}-30$ & 20849.17 & 1391.64 \\
\hline $\begin{array}{l}\text { GDP/EU } \\
\text { pop. }\end{array}$ & 0.814255 & 551691923.09 & 18389730.77 & $9.56488 \mathrm{E}-12$ & 18074.25 & 1037.34 \\
\hline $\begin{array}{l}\text { GDP/CZ } \\
\text { pop. }\end{array}$ & 0.883976 & 551691923.09 & 18389730.77 & $9.56488 \mathrm{E}-12$ & 18074.25 & 1037.34 \\
\hline
\end{tabular}


All 3 mentioned functions show a statistically significant upward trend. The growth of gross domestic product in the USA shows a stable growth rate without significant deviations, which are higher in the case of the Czech Republic and the European Union.

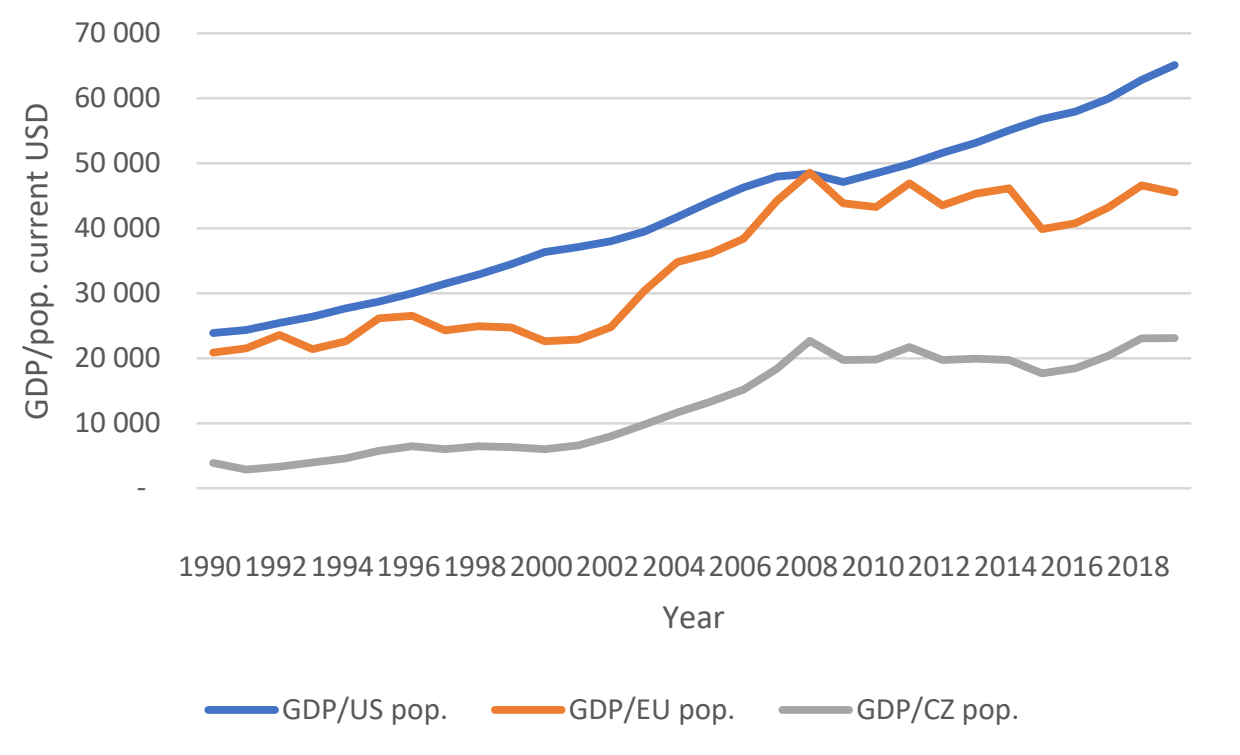

Fig. 1. Development of the gross domestic product per capita [11]

This comparison leads us to several conclusions: 1) In all cases, the gross domestic product is growing. In the reference period, the U.S. economy grew by $3.5 \%$ annually on average. The EU economy grew at a rate of $2.9 \%$ per annum on average. The fastest rate of growth in the reference period was experienced by the Czech Republic which grew by $7.1 \%$ on average; 2) A gap is opening between the performance of the EU and U.S. economy. In 1990, the U.S. gross domestic product per capita was 1.26 times higher than that of the European Union; in 2018, the number was 1.68. In this comparison, the Czech Republic clearly fares better as the U.S. gross domestic product per capita in 1990 was 6.1 times higher than that of the Czech Republic; in 2018, the number was only 2.83. Clearly the livings standards in the Czech Republic are becoming more similar to those of the EU and U.S.; 3)

The Czech and E.U. economy show an identical development and deviation. In both cases, it can be confidently argued that economic cycles have a negative effect at the level of economy (measured in GDP per capita), as evidenced in the 2008/2009 period when both economies experienced a decline, followed by a very slow growth. In 2009 , the biggest drop in GDP per capita occurred in the Czech Republic where it amounted to $13 \%$; for the European Union, it was only $8.9 \%$. Meanwhile, the U.S. economy registered a decrease of mere $2.7 \%$. Furthermore, the U.S. economy is not characterised by as many deviations in growth and there is a trend of relatively slight, stable growth. Foltýn [12] analyses the development of the global economy and of the gross domestic product, searching for causes and the responses of the global economy to global influences. By means of analysis, Felbermayr a Larch [13] concludes that the 2008-2009 economic crisis had a marked effect on the economy of both the United States, and the European Union.

Over the entire reference period (2004-2019), net exports (established as exports minus imports) in the mutual trade between the CZ and USA underwent a relatively stable development, ranging around zero. Negative balance is prevalent, i.e. imports from USA prevail over Czech exports to USA. The period between 2011 to 2013, as well as 2015, is an exception to this. In this respect, a negative balance lowers the value of the gross domestic 
product of the Czech Republic. In modern open economies, direct foreign investments play an important role (the Czech Republic is a country with a prevailing influx of foreign capital). As EU economies become more integrated, we can expect further transfers of the influence enjoyed by multinational companies to domestic business [14]. This also concerns the influx of foreign capital from USA to the CZ which strongly affects the foreign balance of the Czech Republic.

To ascertain the structure of bilateral trade flows between the CZ and USA based on economic quantities (such as GDP or GNI), a foreign trade gravitation model can be utilised. According to Janda, Michalíková, and Potácelová [15], gravitation models can be used for a number of analyses, such as a research into the effect of direct foreign investments on the country's foreign balance. Bubáková [16] provides an overview of the most frequently used variables, such as GDP, GNI, population, currency, political risk, or distance between countries.

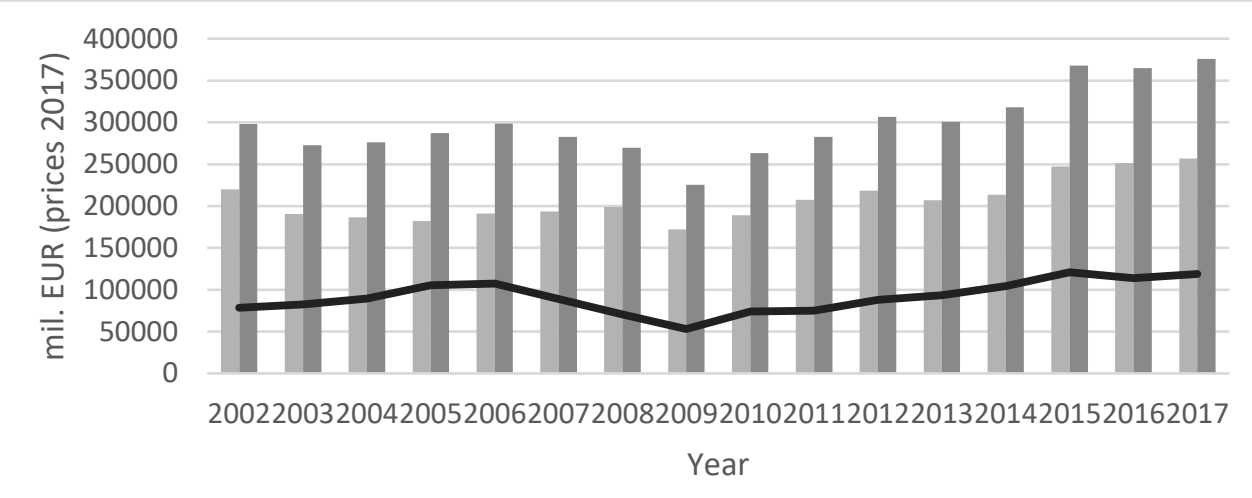

Imports from USA to the EU EU 28 exports to USA

Nett EU exports to USA

Fig. 2 Development of the foreign trade in goods between EU and USA [17]

The European Union, too, registers a positive development of mutual foreign trade. In the reference period (see Chart No. 2), nett exports under mutual trade had a positive value, i.e. EU exports to USA exceeded imports to the EU. Bednáŕ [18] arrives at the conclusion that a liberalisation of the EU-USA trade relationship would strongly increase the amount of goods being exported from the EU to USA, leading to a better allocation of resources and a growth of the EU economy. Šíma [19] pointed out the influence of the demographic structure of the population on consumption and foreign trade.

\section{Conclusion}

As the most influential economy in the world, the U.S. economy has a strong effect on the Czech Republic. Up until 1989 when Czechoslovakia was a closed economy for many citizens, the U.S. economy was perceived as a model example and an "American dream". After the borders opened in 1989, the country's foreign trade quickly boomed, largely thanks to her relationship with the United States. The U.S. culture started becoming apparent in many areas, as evidenced by the fact that English terminology gained a foothold in the Czech (written and spoken) language, American performers became prominent in the Czech media at the expense of Czech artists, or in the changes to the eating habits of Czechs, represented 
by an increased presence of fast-food chains in the Czech Republic. The United States have a significant influence on the Czech economy, as evident in the structure of the mutual foreign trade, for example. The U.S. economy is an important potential selling market for Czech products, despite the growing mutual trade between the Czech Republic and European Union.

\section{References}

1. Marvel, H. P. (1980). Foreign trade and domestic competition. Economic Inquiry, 18(1), 103-122.

2. Lipsey, R. E. (1994). U.S. Foreign Trade and the Balance of Payments, 1800-1913. The National Bureau of Economic Research, 2, Article Number 4710.

3. Shepherd, W. G. (1982). Causes of increased competition in the U.S. Economy, 19391980. The Review of Economics and Statistics, 64(4), 613-626.

4. Davis, L. E., de Souza, J. P. A., Hernandez, G. (2019). An empirical analysis of Minsky regimes in the U.S. economy. Cambridge Journal of Economics, 43(3), 541-583.

5. Hanson, D. (2010). Limits to Free Trade: Non-Tariff Barriers in the European Union, Japan and United States. UK: Edward Elgar.

6. Kahn, A. J., McConnell, M. M., Quiros, P. G. (2002). On the causes of the increased stability of the U.S. economy. FRBNY Economic Policy Review, 5(1), 183-202.

7. Jorgenson, D. W. (2001). Information Technology and the U.S. Economy. American Economic Review, 91(1), 1-32.

8. Strange, S. (1997). The Retreat of the State: The Diffusion of Power in the World Economy. Cambridge: Cambridge University Press.

9. Abboushi, S. (2010). Trade Protectionism: Reasons and Outcomes. Competitiveness Review, 20(5), 384-394.

10. Niu, Z. a kol. (2018). Non-tariff and Overall Protection: Evidence Across Countries and Over Time. Review of World Economics, 154(4), 675-703.

11. World bank. (2020, September 2). World Bank Open Data, Gross domestic product, population. Retrieved from: https://data.worldbank.org/.

12. Foltyn, J. (2001). Stav a tendence vývoje světové ekonomik. Mezinárodní vztahy, 2, 5068.

13. Felbermayr, G. J., Larch, M. (2013). The Transatlantic Trade and Investment Partnership. Potentials, Problems and Perspectives, 14(2), 49-60.

14. Hanousek, J., Kocenda, E., Vozarova, P. (2017). Vliv př́mých zahraničních investic na dodavatelské vztahy a postavení domácích výrobců meziproduktů. Politická ekonomie, 65(4), 391-409.

15. Janda, K., Michalikova, E., Potacelova, V. (2010). Grafitační a fiskální modely státní podproy exportních úvěrů v České republice. Politická ekonomie, 58(3), 305-325.

16. Bubakova, P. (2013). Gravitační model mezinárodní směny, jeho proměnné, předpoklady, problem a aplikace. Acta Oeconomica Pragensia, 21(2), 3-24.

17. Eurostat (2020, Sempember 8). Eurostat Database. Retrieved from: http://ec.europa.eu/ eurostat.

18. Bednar, M. (2019). Obchodně-politické překážky vývozu zboží z Evropské unie do USA: Význam liberalizace obchodních toků. Politická ekonomie, 67(3), 231-252.

19. Sima, O. (2020). Reálná ekonomika jako zdroj nerovnováhy obchodní balance-základní př́stup, 2020. Politická ekonomie, 68(3), 322-347. 